\title{
Whole-building design for a green school building in Al-Ain, United Arab Emirates
}

\author{
S. K. Elmasry \& M. A. Haggag \\ UAE University, United Arab Emirates
}

\begin{abstract}
Energy efficiency in school buildings has been an international concern for the last few decades. Green-schools initiatives and benchmarks have been developing worldwide, for example Leadership in Energy and Environmental Design (LEED) for school buildings by the U.S. Green Building Council (USGBC), Energy Smart School Program by the U.S. Environmental Protection Agency (EPA). Also, the UK has been producing energy benchmarks and performance guides for almost 30 years, such as Good Practice Guide 343, which includes typical and best practice values for primary school.

In 2009, the Estidama Pearl Rating System for school buildings emerged as a local effort in the United Arab Emirates following the Estidama sustainability initiative under the umbrella of the AbuDhabi plan 2030. As part of the Pearl Building Rating System, sustainable performance of schools buildings is assessed against seven main criteria, namely Integrated Development Process (IDP), Natural Systems (NS), Precious Water (PW), Resourceful Energy (RE), Stewarding Materials (SM), Innovating Practice (IP), and finally Livable Buildings (LB).

Based on this initiative and the hot arid climatic condition of Al-Ain city, a research team at the United Arab Emirates University has initiated a study of whole-building design of an International School as part of a long-term research agenda for sustainable applications in school buildings in the area. The building is currently performing with photovoltaic panels' installations, grey water recycling strategies as well as green wall applications. This paper previews the sustainability approaches and systems established in the building, and examines the integrated performance of the building against the Estidama rating criteria recommended for the area. The paper concludes a set of recommendations for
\end{abstract}


sustainable design criteria for school buildings following the Estidama initiative tailored for school buildings using the whole-building design approach.

Keywords: Estidama, hot arid climate, school building, UAE, whole-building design.

\section{Introduction}

Schools are generally buildings of high energy consumption due to their highoccupancy levels and their unique occupancy patterns. According to estimates of the US Department of Energy, 25\% of the expenses on energy in schools could be saved through better building design and using energy-efficient technologies combined with improvements in operations and maintenance [1]. Classrooms, as the most common functional space, result in very large values of the internal heat sources (approximately $5 \mathrm{~kW}$ ). As a result, existing design guidelines for low energy consumption in residential [1] or office buildings [2] may not hold for classrooms design, where usage pattern is different and internal heat gains are much larger $[1,3]$.

In the city of Al-Ain, United Arab Emirates, a local sustainable school initiative was taken by the administration of Liwa International School (LIS). The school is sited in the south west end of Al-Ain city, the inner desert oasis of the UAE. The school building was constructed in 1992 and converted from conventional to sustainable green building in 2010. As a member of the global network of UNESCO affiliated schools, LIS has participated in the World Future Energy Summit 2010 with a sustainable green building project. This project aimed to increase energy efficiency in buildings by introducing green building technologies. As part of an experimental work which was carried out by the authors in 2010 [4], this pilot project was selected as a case study to investigate the performance of the installed systems as part of developing the future agenda of energy-efficient school buildings in the U.A.E.

The school occupies 2 separate buildings located in the south west end of $\mathrm{Al}$ Ain city; the northern building or the main building (A) hosting the elementary and secondary classrooms as well as the administration, and the southern building (B) hosting the kindergarten section. The campus is specifically located at latitude $24^{\circ} 16^{\prime}$ and longitude $55^{\circ} 36^{\prime}$ E., as illustrated in Figure 1.

The 2010 project of transforming the building into an energy-efficient educational facility has resulted in introducing 3 systems to the buildings, namely (a) the green wall system; aiming at reducing the heat gain through the building facades. The system has been installed in phases on all building facades consequently. (b) Photovoltaics; installed on the roofs on both buildings, aiming at providing the capacity needed for night lighting and irrigation of the green walls, and (c) grey water recycling system, aiming at producing the capacity of water needed for irrigation.

It is essential however to discuss the need for and the efforts towards energy efficiency in general and in school buildings in specific as the umbrella under which this project falls. 

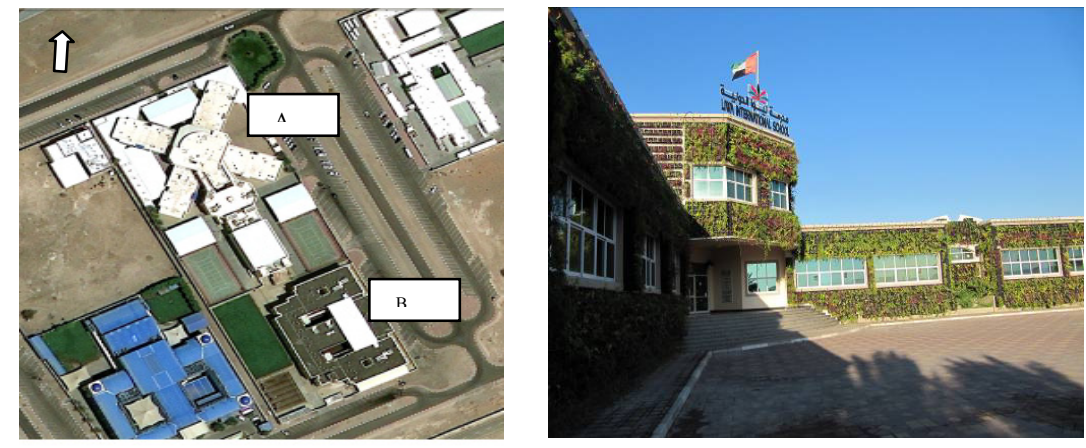

Figure 1: $\quad$ Satellite image for the LIS campus showing the main building (A) and the Kindergarten building (B). Front image of the main building.

\section{Energy efficiency and assessment tools for school buildings}

Starting the 1990s, energy efficiency in buildings emerged as a global concern given that buildings contribute to $20-40 \%$ of global energy consumption in developed countries [5]. A number of building assessment tools, benchmarking, and rating systems have been introduced to the building industry offering new values in terms of building performance in general and its environmental responsiveness in specific. When it comes to the special nature of school buildings, developers were conscious enough to tailor these tools to the needs of building type with its unique occupancy patterns, and energy demands. The following sections illustrate international and local efforts in the area.

\subsection{International building assessment tools}

Building assessment tools address building performance from diverse approaches. LEED for example, provides third-party verification that a building or a development was designed and built using strategies which provide performance across a number of the metrics; energy savings, water efficiency, $\mathrm{CO} 2$ emissions reduction, improved indoor environmental quality, and stewardship of resources and sensitivity to their impacts [6]. Building performance in LEED is measured and evaluated a point-scale system. BREEAM is another tool which measures sustainability of buildings in the UK. It assesses the building components along its lifecycle to ensure that the accreditation is still valid [7, 8]. SBTool [9], formerly known as GBTool [10, 11] is intended to be used for the assessment of potential energy and environmental performance of buildings. It can handle types of buildings: Multi-unit residential; Office and School. In GBTool, scores are assigned in a range of -2 to +5 , where: - 2 and -1 are levels of performance below the acceptable level in your region, for occupancies specified; 0 is the minimum level of acceptable performance in 
your region for occupancies specified; 3 is Best Practice; and 5 is the best technically achievable, without consideration of cost.

When it comes to energy performance and assessment of school buildings, it is often devoted in the literature to savings via specific features such as utilization of solar energy, construction features, such as thermal insulation, thermal mass, and shading, HVAC performance, and geothermal pumps [2, 3, 12]. However, basic assumptions regarding thermal comfort, indoor air quality, occupancy and acclimatization schedules, internal loads, and architectural features of the school building are not identical in the various publications, and are usually based on local preferences [3]. International efforts have thus been aiming to develop tailored strategies to meet the specific demands for school buildings, and to meet local or regional demands.

Green schools benchmarks have been developing worldwide, for example Leadership in Energy and Environmental Design (LEED) for school buildings by the U.S. Green Building Council (USGBC) [12], Energy Smart School Program by the U.S. Environmental Protection Agency (EPA) [2], The Benchmarking Guide for School Facility Managers as part of the pilot benchmarking and best practices program undertaken by Natural Resources Canada's (NRCan's) Office of Energy Efficiency (OEE) [13]. Also, the UK has been producing energy benchmarks and performance guides for almost 30 years, as Good Practice Guide 343, which includes typical and best practice values for primary schools [14]. These tools proved success in terms of meeting the patterns of energy consumption and savings in school buildings.

\subsection{Estidama, a local Emirati assessment tool}

The implementation of any of the previously mentioned assessment tools in the context of UAE is in fact inappropriate, since they do not particularly address the local environmental, economical, cultural and social contexts, which are the derivers the broader goal of sustainability.

In May 2008, the Estidama Pearls Rating System was initiated in Abu-Dhabi, U.A.E. and added to the international list [15]. The system targets the mid-east region and addresses the impact which the built environment has in establishing sustainability in an integrative design process, taking into consideration four pillars of sustainability; the local environment, economy, culture and society. Estidama is distinguished from previous building evaluation tools by the following [15-17]:

1. The system is organized around five core concepts specifically targeting sustainability; Living Systems, Livable City, Precious Water, Resourceful Energy, and Stewarding Materials.

2. The 'how to' is enabled by the Estidama Integrative Design Process (EIDP) concept and Innovative Practice. Under this structure stakeholders will be driven to think about sustainable development as an integrated process of design, construction and operation [16]. 
3. Building sustainability is evaluated holistically within the local context of the U.A.E., the regional context of the mid-east, as well as within the global context (5 pearls rating).

4. Building evaluation occurs as well as through the building life cycle.

5. Each building type use typologies adopted by Estidama has a different emphasis or weighting in the context of Abu-Dhabi. For example, points accredited for development density is weighed by 2 credit points for office buildings, 4 credit points for retail, while it is not considered for residential buildings.

In 2009, Estidama Pearl Rating System for school buildings emerged as a local effort in the UAE following the Estidama initiative [18]. As part of the Pearl Building Rating System, sustainable performance of schools buildings is assessed against seven main criteria, namely Integrated Development Process (IDP), Natural Systems (NS), Precious Water (PW), Resourceful Energy (RE), Stewarding Materials (SM), Innovating Practice (IP), and finally Livable Buildings (LB) which covers 2 subcategories; Livable Outdoors (LBo), and Livable Indoors (LBi).

In LIS, the school building under study, the main sustainable additions to the building were in the form of 3 systems; green walls, Photovoltaics and grey water recycling systems. These systems directly address the Estidama criteria of Integrated Development Process (IDP), Natural Systems (NS) Precious Water (PW) and Resourceful Energy (RE), as explained in the following sections.

\section{Estidama criteria and sustainable building systems at LIS}

\subsection{The green wall and natural systems criteria (NS)}

The Estidama NS criteria extend to the concept of creating a 'green gradient.' It also reflects the 'green infrastructure' strategy in plan and form, as well as in implementation, leading to healthier ecosystems, habitats and ultimately communities [18]. The Green wall system installed at LIS, directly addresses this criteria. More specifically, it directly establishes the following according to the rating system; the provision of a natural system design and management strategy; enhancement in ecological value; and habitat creation, restoration and provision of habitat connection.

A number of studies have been studying the impact of green walls on reducing cooling demand in buildings [19-23]. In their study, Wong et al. [19] concluded that in Canada, there is proven evidence that vertical greenery systems can reduce air conditioning load by shading walls and windows from incoming solar energy resulting in a $5.5^{\circ} \mathrm{C}$ reduction in the immediate outdoor temperature and a corresponding energy reduction by $50-70 \%$. While the shading effect was found to reduce the energy cooling load by about $23 \%$ and the usage of fans by $20 \%$ resulting in an $8 \%$ reduction in annual energy consumption. Results also show that vertical greenery systems can block incoming solar radiation, thus minimizing the amount of heat through the façade. To achieve the intended 
amount of thermal reduction, the thermal transfer value of the envelope and the leaves coverage of a plant are useful design variables.

Also, acts of urbanization worldwide result in significant changes in the thermal properties of surface materials and phenomena such as Urban Heat Island (UHI) effect have been forced. Alexandri and Jones [20] highlight the important effect of green walls is reducing the heat island effect in microclimates in urban settings. The study also suggests that if applied to the whole city scale, green roofs and walls could mitigate raised urban temperatures, and especially for hot climates, achieve energy saving for cooling buildings from $32 \%$ to $100 \%$.

Green walls also contribute towards sound reduction, which is an influential issue in school applications. They have an acoustical insulation that is far better (up to $30 \mathrm{db}$ ) than that of exposed wall [22]. The degree of sound insulation provided by the green wall depends mainly on factors that influence noise reductions including depth of the growing media, type of plants, the materials used for the structural components of the living wall system, and the layer of air between the plants and the wall.

The use of green walls as visual attractants increases the value of the building. Moreover, green walls can help to address the lack of green space in urban environments. Plants improve human health, capture airborne pollutions, and filter harmful gases. In addition to absorbing heat and increasing thermal performance, the green wall helps to filter the air moving across it.

In LIS, The existing buildings' skin is composed of $20 \mathrm{~cm}$. hollow block wall covered with plaster. A green wall was installed on the building facades as illustrated in Figure 2. The system is composed of the following elements:

- Holding boxes: $30 \times 30 \times 25 \mathrm{~cm}$ plastic boxes made of installed connectively on the facades.

- Drip irrigation pipes: $13 \mathrm{~mm}$ pipes are installed within the boxes as a drip irrigation system for the vegetated wall, and

- Plant Foliage: holding a variation of plant species.

As of date, this system is the only one experimentally monitored across the school building. Using temperature data loggers, measurements were taken on and around the internal and external surfaces of wall as well as the ambient temperature on both sides of the wall. Temperature measurements were taken in two situations: (a) locations with the vegetated walls installations, and (b) locations without vegetated wall installations. The readings took place in 2 weeks during October and November 2010.

It was observed that the temperature difference between green and bare facades was higher at the start of the experiments at end of October which continued to decrease as the experiments proceeded towards mid of November. In order to further understand the effect of green façade on the indoor climate the trend in temperature difference between outdoor and indoor ambience is shown in Figure 3. 

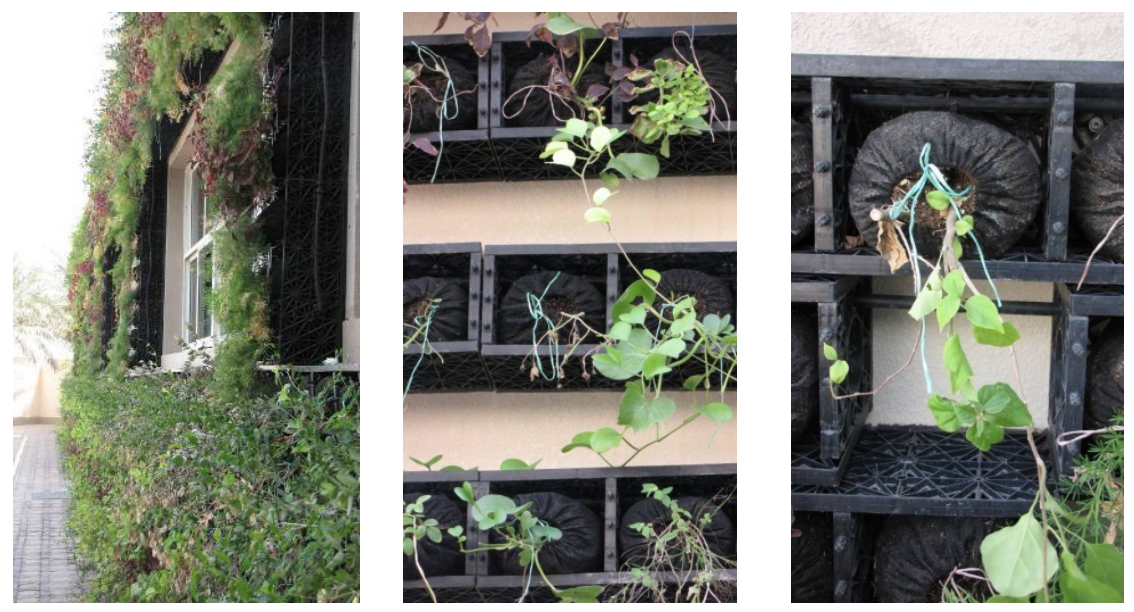

Figure 2: Green wall installations at LIS, Al Ain.

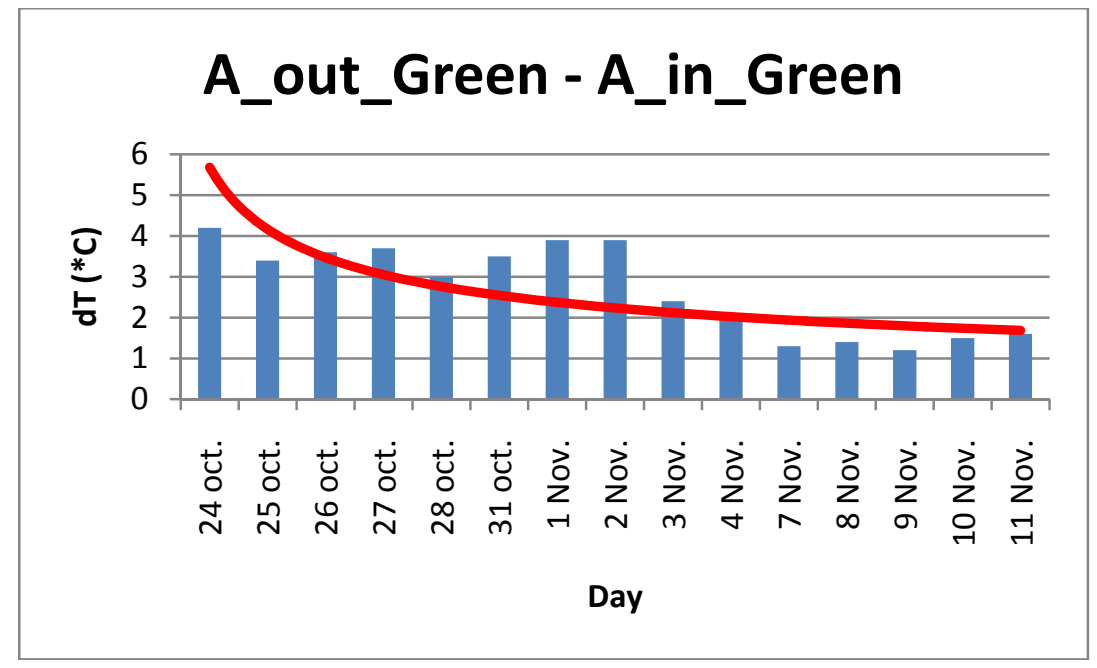

Figure 3: Trend in temperature profiles to predict seasonal performance of the green wall installation at LIS.

Figure 3 shows that the temperature difference continued to decrease as was the gradient of decrease because the outdoor ambient temperatures started decreasing due to approaching winter. The temperature difference dropped from little above $4^{\circ} \mathrm{C}$ to little above $1^{\circ} \mathrm{C}$ in three week time. Provided the trend in temperature decrease continues, a negative temperature difference is expected in winter months which means the indoor temperature would be higher than 
outdoor which is exactly what is required. The higher indoor temperature would increase thermal comfort in the winter months, however long time data is required to validate this prediction unavailable at this stage [4].

\subsection{Grey-water recycling and precious water criteria (PW)}

Because of the limited annual rainfall, hot climate, and the significant energy embodied in potable water due to desalinization in the UAE, water conservation is a priority for Estidama. It is a distinct possibility that the UAE will become even drier due to the effects of global warming. Coupled with projected population increases, the importance of accelerating water conservation and reuse efforts is clear [18].

Grey water is a strategy which may be considered to meet these criteria. Wastewater composes $50-80 \%$ of residential wastewater, while the remainder being sewage or black water [24]. In many urban areas with water shortage, grey water is recorded as the second source of domestic water supply with an average of $50 \%$ after the municipality water supply and the most common source of water for the gardens and landscaping (35\%) [25].

Grey water recycling system has a number of benefits: (a) reducing water consumption by minimizing fresh water usage;(b) reducing the chemical used for water treatments; and (c) reducing energy use; and increasing plant growth.

In LIS, two purification tanks are installed with a capacity of 3000 Gallons each. However, the actual collected grey water per day is $1.47 \mathrm{~m}^{3}$ from each tank (with a total of $2.94 \mathrm{~m}^{3}$ per working day). This amount of grey water is used only for irrigating the green walls along with municipal supplies. The irrigation system covers only two 5-6 minutes irrigation cycles per day. It should be mentioned that this system is currently under monitoring by the research team and in terms of reduction in annual consumption, and potential reductions in utility bills. Figure 4 illustrates the water tanks and filters installed.
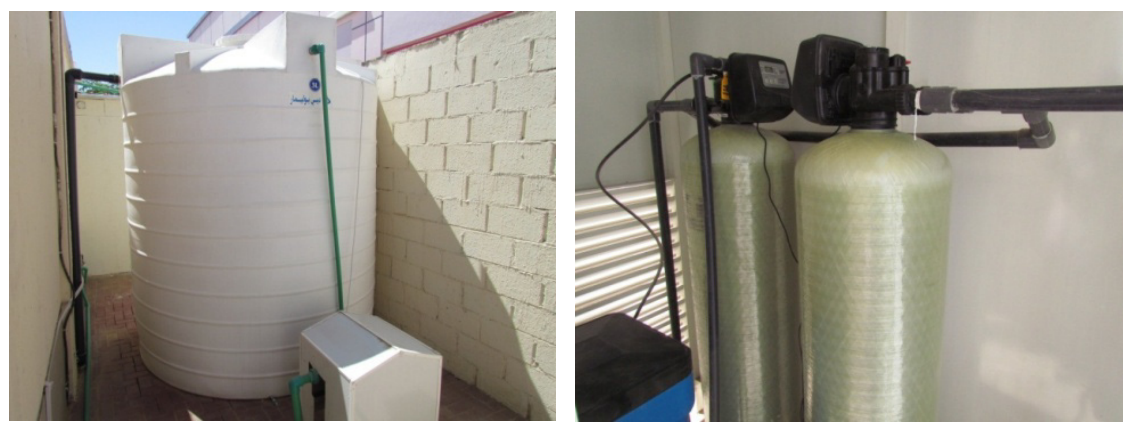

Figure 4: Grey water tanks and filters installed at LIS. 


\subsection{Photovoltaics and resourceful energy criteria (RE)}

Within the Estidama Resourceful Energy section emphasis is on reducing the demand for energy through passive environmental design, appropriate selection of highly efficient mechanical and electrical equipment, and the facilitation of renewable energy installations [18].

Photovoltaic panels installations directly contribute towards these criteria. When they displace conventional building materials, savings in the purchase and installation of the latter lowers the net cost. They can, in high-volume production, lead to lower substrate, distribution and installation costs. Roofs in particular offer an attractive location for this kind of installation because of unshaded solar access and that flat-roofs generally enable more optimal solar cell placement and orientation. All PV manufacturers provide performance information at STC and which include open circuit voltage, short circuit current, MPP voltage current, power and efficiency and temperature coefficients. All these parameters at STC are not sufficient to predict the operation of each PV technology under outdoor conditions. Because of this the performance outcome of the energy yield, the outdoor efficiency and performance ratio (PR) from independent outdoor PV technology assessments are becoming important [25]. Performance of PV systems is directly related to environmental and operational conditions. An assessment of the effects of irradiance, temperature, soiling and power rating on the performance comparison of each technology has been made [27].

At LIS, 62 photovoltaic panels of Maximum Power $($ Pmax $)=128 \mathrm{~W}$, are installed on the roof of the main building (A). Two groups of batteries, $6212 \mathrm{~V}$ 200AH batteries collectively, are located in an adjacent room. On the roof of the kindergarten building (B), 12 panels are similarly installed along with 12 batteries for storage. The energy collected from this system is currently used for night landscape light and operating the grey water purification plant. Productivity of the system and resulting, energy savings are currently under investigation by the research team.

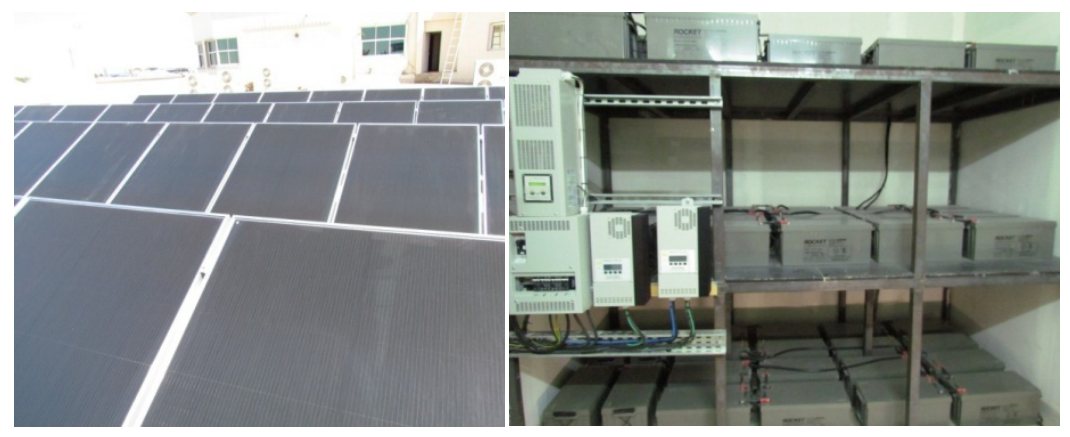

Figure 5: Photovoltaic panels installations at LIS. 


\section{Conclusion}

The Estidama rating system developed with the aim of introducing Estidama to the Emirati built environment is an essential consideration for future school buildings which are characterized by its unique occupancy and energy consumption patterns. In the city of $\mathrm{Al}$ Ain, an individual attempt for transforming a conventional school building into a sustainable campus, has resulted in integrating 3 systems; namely the green wall, photovoltaic panels and grey water recycling, which contribute directly in the following Estidama criteria:

- Integrated Development Process (IDP): this directly relates to the design process. However, it falls beyond the scope of this paper.

- Natural Systems (NS): this criteria was met in the pilot school under study through the installation of green walls, which proved to be an efficient system in the duration of the initial data acquisition and analysis process in a number of ways, one is that during winter months it is expected that during winter months, the temperature inside the green wall is expected to be higher than the outdoor temperature.

- Precious Water (PW): this was addressed through a grey water recycling system which efficiently supplies the irrigation system for the green wall with support from the municipal supplies. The system is currently under monitoring for further analysis and developing digital models simulating system performance for future practice.

- $\quad$ Resourceful Energy (RE): a criterion which was addressed by installing photovoltaic panels which provide the energy for night light as well as operating the filters of the grey water system.

The pilot project presented in this paper illustrates an early attempt for school buildings in the UAE to adopt sustainable approaches to enhance their energy performance. This project is currently under monitoring and analysis, and the results are being used to draw design recommendations which support the Estidama rating for future school buildings in the UAE.

\section{References}

[1] Perez. Y., \& I. Capeluto, Climatic considerations in school building design in hot-humid climate for reducing energy consumption, Applied Energy, 86, pp 340-348, 2009

[2] U.S. Environmental Protection Agency (2007). ENERGY STAR® and Other Climate Protection Partnerships 2007 Annual Report. http://www.energystar.gov/ia/news/downloads/annual_report_2007.pdf. Access Date: December 2010.

[3] Becker, R. et al., Improving energy performance of school buildings while ensuring indoor air quality ventilation, Building and Environment, 42, pp 3261-3276, 2007 
[4] Haggag, M. et al, 2010, Integrating Advanced Facades for Low-Energy Building Performance: Intelligent Design Criteria for the UAE, Individual Research Project, UAEU

[5] Perez-Lombard, L. et al. A review of benchmarking, rating and labeling concepts within the framework of building energy certification schemes. Energy and Buildings 41, pp.272-278, 2009.

[6] U.S. Green Building Council. http://www.usgbc.org/DisplayPage.aspx? CategoryID=19. Access Date: October 2009

[7] BREEAM. http://www.breeam.org/ .Access date: March 2011.

[8] BREEAM, Wiki. http://en.wikipedia.org/wiki/BREEAM Access Date: March 2011.

[9] SBTool. http://greenbuilding.ca/iisbe/sbc2k8/sbc2k8-download_f.htm Access Date: October 2009

[10] GBC2000. http://www.iisbe.org/gbc2k/gbtool/gbtool-main.htm. Access Date: March 2011

[11] GBTool.http://www.petus.eu.com/left.php?sct=6\&sbsct=2\&pageid=155\&p agesect $=0 \&$ pagelang=en. Access Date: March 2011

[12] U.S. Green Building Council (2007). LEED® for Schools for New Construction and Major Renovations. http:/www.usgbc.org/ ShowFile.aspx?DocumentID=2593. Access Date: December 2010

[13] Natural Resources Canada, Office of Energy Efficiency (2001). Benchmarking guide for school facility managers. http:/oee.nrcan.gc.ca /Publications/commercial/pdf/m92-221-2001E.pdf. Access Date: December 2010

[14] Hernandez, P. et al., Development of energy performance benchmarks and building energy ratings for non-domestic buildings: An example for Irish primary schools, Energy and Buildings, 40, pp. 249-254, 2008.

[15] Estidama. http://www.estidama.org/Default_en_gb.aspx. Access Date: March 2011

[16] Estidama, The Pearls Design System: New buildings rating method (May 2009) Update Release.

[17] Urban Planning Council, Abu Dhabi. Integrated Design as a foundation for Estidama. (January, 2009), http://www.estidama.org/\$Common/Doc/ IntegratedDesignAsAFoundationForEstidama.pdf. Access Date: October 2009

[18] AbuDhabi Urban Planning Council (2010). The Pearl Rating System for Estidama Building Rating System, Design \& Construction (Version 1.0). http:/estidama.org/template/estidama/docs/PBRS\%20Version\%201.0.pdf .Access Date: December 2010.

[19] Wong, N. et al., Energy simulation of vertical greenery systems, Energy and Buildings, 41, pp 1401-1408, 2009

[20] Alexandri, E. \& P. Jones, Temperature decreases in an urban canyon due to green walls and green roofs in diverse climates, Building and Environment, 43, pp 480-493, 2008

[21] Wong, N. et al., Thermal evaluation of vertical greenery systems for building walls, Building and Environment, 45, pp 663-672, 2010 
[22] Kontoleon, K. \& E. Eumorfopoulou, The effect of orientation and proportion of a plant-covered wall layer on the thermal performance of a building zone, Building and Environment, 45, pp 1287-1303, 2010

[23] Eumorfopoulou, E. \& K. Kontoleon, Experimental approach to the contribution of plant-covered walls to the thermal behavior of building envelopes, Building and Environment, 44, pp 1024-1038, 2009

[24] Mississippi Agricultural and Forestry Experiment Station. http:/msucares.com /lawn/landscape/sustainable/greywater.html Access Date: April 2011.

[25] ABS, 2007, Environmental Issues: People's Views and Practices, March 2007 (cat. no. 4602.0)

[26] Makrides, G. et al., Temperature behavior of different photovoltaic systems installed in Cyprus and Germany, Solar Energy Materials and Solar Cells, 93, pp. 1095-1099, 2009

[27] Zinsser B. et al., Rating of annual energy yield more sensitive to reference power than module technology, 35th IEEE Photovoltaic Specialists Conference Proceedings, pp. 1095-1099, 2010 